\title{
Analysis of User Satisfication with Graduates in Statistical Study Program Universitas Terbuka
}

\author{
Siti Hadijah Hasanah ${ }^{1}$, Dewi Juliah Ratnaningsih ${ }^{2}$ \\ Departement of Statistics, Faculty of Science and Technology, Universitas Terbuka, Indonesia
}

\begin{tabular}{l}
\hline \hline Article Info \\
\hline Article history: \\
Received : $08-07-2021$ \\
Revised : $10-15-2021$ \\
Accepted : 10-18-2021 \\
\hline Keywords: \\
Customer Satisfaction Index; \\
Fishbein; \\
Gap; \\
IPA; \\
Open and Distance Learning. \\
\hline
\end{tabular}

ABSTRACT
Revolution 4.0 requires the Universitas Terbuka Statistics study program to change the educational
curriculum that aims to produce quality graduate competencies. Therefore, to collect information
and evaluate the competence of graduates, it is necessary to conduct tracer study research on each
graduate. This study aims to measure user satisfaction with graduate competencies using Gap analy-
sis, Importance-Performance Analysis (IPA), Customer Satisfaction Index (CSI), and a multi-attribute
Fishbein model. Based on the value of Gap and Science, the main priority that must be improved by
graduates to meet user expectations is the ability to solve problems, generate ideas, and be able to
present the results of these ideas in the form of reports/journals. The value of the level of suitability
between user satisfaction and the importance of the ability of graduates is very good at $92.87 \%$ and a
CSI value of $78.25 \%$, which means that overall user satisfaction with graduates is good, besides that
based on the results of the multi-attribute Fishbein model, an Ao value of 158.20 which means that
graduate users have a positive attitude towards the abilities of UT Statistics program graduates.

Accredited by Kemenristekdikti, Decree No: 200/M/KPT/2020

DOI: https://doi.org/10.30812/varian.v5i1.1331

Corresponding Author:

This is an open access article under the CC BY-SA license.

Siti Hadijah Hasanah,

Departement of Statistics, Faculty of Science and Technology.

Email: sitihadijah@ecampus.ut.ac.id

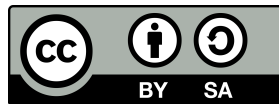

\section{A. INTRODUCTION}

The very rapid development of technology in the current era has significant impact on the world of education. All activities in the world of education are now digitally based. Digital technology is a system of electronic devices and resources that generate and store data from the teaching and learning process (Kumi-Yeboah et al., 2020) even the World Wide Web facilitates the world's population and moves all distance education information to the digital era (Fidalgo et al., 2020). Open and distance learning systems focus on open access in the world of education, which creates constraints on students in terms of place, time and provides flexible learning opportunities for students to enable them to attend formal education at the University (Lassoued et al., 2020). Distance education is based on the theory of independence of students without having to interact face-to-face with educators (Abrami et al., 2011; Picciano, 2017). Universitas Terbuka (UT) has a distance and open learning system by UT's Vision, which is to become a world-quality open and distance university. The first university in Indonesia to implement a distance learning system in Indonesia. UT has 39 service offices spread across Indonesia and abroad. As for the convenience for those who wish to continue studying undergraduate UT, namely, there are no restrictions on the duration of study completion, there is no application of the dropout system, there are no restrictions on the graduation year of the diploma or age, and registration time is free throughout the year.

UT Statistics Study Program is under the Faculty of Science and Technology, which was previously named the Faculty of Mathematics and Natural Sciences, which has a vision of becoming a quality Statistics study program with an open and longdistance higher education system. The Bachelor of Statistics study program has succeeded in graduating students from Sabang to Merauke with various characteristics of students. Along with the times as well as science and technology that occurred in the era 
of the Industrial Revolution 4.0, a Statistics study program is required to follow the changes that occurred in the 4.0 era. The effort made by the Statistics study program is to evaluate the ability of graduates in the world of work to produce quality graduates.

This evaluation is necessary so that there is no gap between the curriculum produced by universities and the world of work of graduates. Changes in all fields also affect the world job market. The development of science and technology is very rapid, causing changes in terms of qualifications, competencies, and requirements for entering the work environment (Renny et al., 2013). Therefore, to collect information and evaluate the results of the performance of the graduates, a tracer study is needed in the Statistics study program.

Customer Satisfaction Index (CSI) is an index value that is used to determine the overall level of user satisfaction by considering the importance of the attributes being measured, for example, the application of CSI is one of them in the field of education (Arabia, 2021; Yanova, 2015). Measuring user satisfaction in education is an important tool for developing an evaluation of the quality of an education [4]. Meanwhile, to map some of the attributes that become research indicators from the top priority to the lowest according to graduate users, the Importance-Performance Analysis (IPA) analysis is used (Vieira et al., 2019), several studies that apply science in their research such as in the field of education (Silva and Fernandes, 2010), Agribusiness (Lubis et al., 2020), and Economics (Wade and Eagles, 2003). Multi-attribute Fishbein is used to analyzing user attitudes towards graduates with several attributes, examples of its application in the fields of Agribusiness (Widayanti et al., 2020), Education (Jasuli, 2018), and Economics (Kumari, 2020). Researchers carried out 3 methods at once to find out users' perceptions of the abilities of graduates, and this was rarely done by previous researchers, where they mostly used one of the 3 methods. This research is used as an evaluation material in terms of the career development of graduates of the Statistics study program after they finish their education at UT and as a way to increase UT Statistics accreditation. The following are the objectives of this study, namely: what indicators are expected by users on the performance of graduates; what is the user's perception of the performance of graduates using the Importance-Performance Analysis method; how is the level of conformity and the value of CSI on the perception of user satisfaction with graduates; what is the user's perception of graduates using Fishbein's multi-attribute model.

\section{B. LITERATURE REVIEW}

\section{Validity and Reliability Test}

The validity test is used to find out whether each item that is an indicator of the level of user satisfaction with the interest of the graduate's ability is valid, namely by comparing the calculated r-value and r-table, if the calculated r-value is greater than the r-table then the item is said to be valid. While the reliability test is to determine whether the items that become indicators are reliable, where the Cronbach alpha value obtained must be greater than 0.6 , so all items can be said to be reliable (Taber, 2018).

\section{Level of Conformity}

The Level of conformity aims to calculate the percentage level of user satisfaction with the interests of graduate abilities. The higher the level of suitability reflects the higher the level of user satisfaction with the interests of the ability of graduates, and if the value of the suitability level is close to $100 \%$ or above the average, the level of suitability is said to be good.

$$
\text { Level Of Convormity }=\frac{\text { Performance }}{\text { Importance }} \times 100 \%
$$

\section{Importance-Performance Analysis (IPA)}

Importance-Performance Analysis (IPA) is a graph shown in a 2-dimensional coordinate system and divides the area into 4 quadrants (Feng et al., 2014). IPA consists of two analyzes, Gap and quadrant analysis. Gap analysis is the difference between the level of performance and the level of importance (Wade and Eagles, 2003). This gap is used to see the gap between user satisfaction and the importance of the ability of graduates. Meanwhile, quadrant analysis is used to determine the user's response to the variables plotted based on the level of importance of the ability of graduates. 


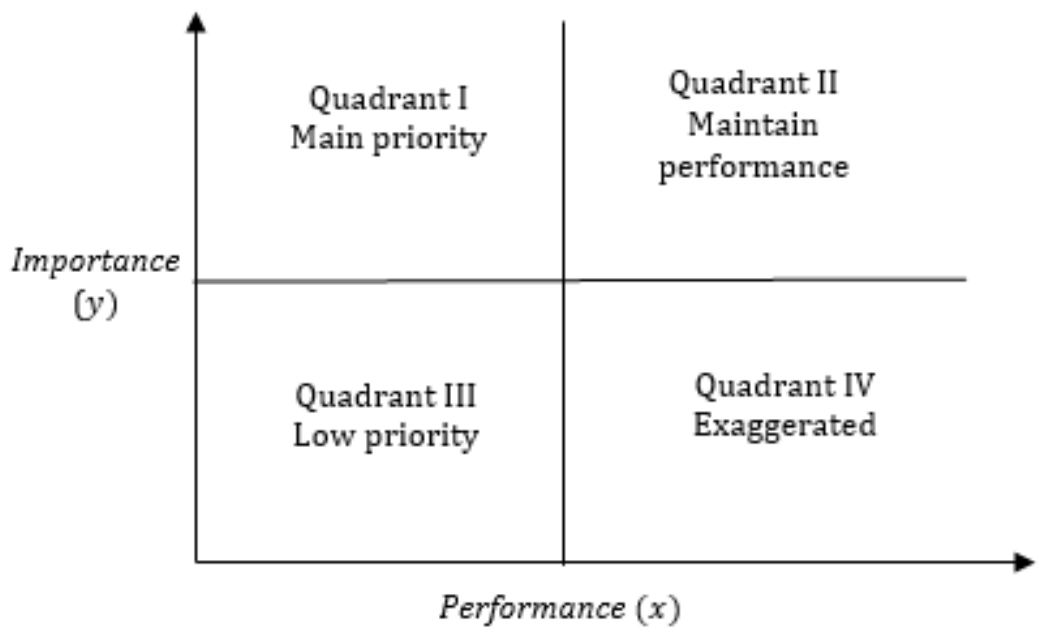

Figure 1. Importance-Performance Analysis quadrant

Figure 1 explains that quadrant I am the main priority expected by users to graduates, the performance abilities contained in this quadrant must be further improved by graduates in the work environment. Quadrant II the ability of graduates is good and in accordance with user satisfaction, the indicators in this quadrant must be maintained in the work environment. Quadrant III of the user's perception of the importance of the ability of graduates in this quadrant is a low priority for them and users do not care that the attribute of the ability of graduates in this quadrant is low. Quadrant IV shows the attributes that are considered less important by users but graduates have a very good performance on these attributes so that users assess the performance of graduates too much in this quadrant.

\section{Customer Satisfaction Index (CSI)}

Customer Satisfaction Index (CSI) aims to measure the level of satisfaction of graduate users as a whole based on the level of importance of the graduate ability.

$$
C S I=\frac{\sum_{k=1}^{p} W S_{k}}{H S} \times 100 \%
$$

where:

$W S_{k} \quad=$ Weighted Average

HS = Highest Scale

User satisfaction criteria are in the Table 1 below:

Table 1. User Satisfaction Criteria

\begin{tabular}{lll}
\hline \multicolumn{2}{c}{ Value (\%) } & Description \\
\hline 25.00 & 64.99 & Very less \\
65.00 & 76.60 & Less \\
76.61 & 88.30 & Good \\
88.31 & 100.00 & Very good \\
\hline
\end{tabular}

\section{Fishbein Multi-attribute Attitude Model}

Fishbein is used to determining the relationship between user attitudes towards graduate performance based on the attributes they have. If the performance of the graduates is very good, the users will give a very positive attitude towards the graduates.

$$
A_{o}=\sum_{i=1}^{n} b_{i} e_{i}
$$




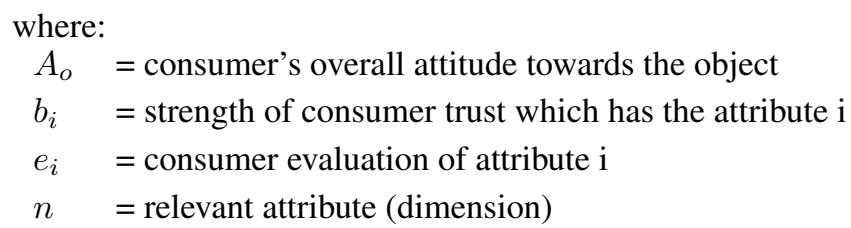

\section{RESEARCH METHOD}

The data used in this tracer study research is primary data obtained directly from graduates and graduate users in 2019 through a structured questionnaire. The implementation of the tracer study consists of making instruments and developing questionnaires, collecting data, processing data, analyzing data, and drawing conclusions. The following are 15 attributes used to analyze user satisfaction with the importance of the abilities of graduates.

\begin{tabular}{cl}
\begin{tabular}{c} 
Table 2. Attributes of User Satisfaction to Graduate Performance \\
\hline Attribute
\end{tabular} & \multicolumn{1}{c}{ Description } \\
\hline 1 & Mastery of the field of science pursued at UT \\
3 & Knowledge of other fields of science \\
4 & Analytical thinking \\
5 & The ability to acquire new knowledge quickly \\
6 & Ability to negotiate effectively \\
7 & Ability to coordinate activities \\
8 & Ability to manage time efficiently \\
9 & Ability to work productively with others \\
10 & The ability to empower others \\
11 & Ability to use a computer or the internet \\
12 & Problem-solving skills \\
13 & The ability to generate ideas \\
14 & The ability to present the results of ideas \\
15 & Ability to write reports \\
\hline
\end{tabular}

Table 3. Satisfaction and Importance Level Assessment Scores

\begin{tabular}{lll}
\hline \multirow{2}{*}{ Weight } & \multicolumn{2}{c}{ Level } \\
& Importance & Performance \\
\hline 1 & Not needed & Very less \\
2 & Less needed & Less \\
3 & Needed & Good \\
4 & Very needed & Very good \\
\hline
\end{tabular}

Validity and Reliability Test

1. If the calculated $r$-value is greater than the r-table then the item is said to be valid.

2. If the Cronbach alpha value obtained is greater than 0.6 then all items are said to be reliable.

The following are the steps used to determine the value of the Customer Satisfaction Index (CSI) as follows:

1. Determine the Mean Importance Score (MIS) and Mean Satisfaction Score (MSS)

2. Determine Weight Factors (WF)

3. Determine the Weight Score (WS)

4. Determine the Weight Total (WT)

5. Determine the Customer Satisfaction Index (CSI) 
The following are the steps used in the Importance-Performance Analysis (IPA) method as follows:

1. Gap Analysis (GAP)

The value resulting from the difference in performance value with the importance

2. Quadrant analysis

Analysis of the attributes contained in each quadrant I, II, III, and IV

The following are the steps used in the Fishbein multi-attribute attitude model method as follows:

1. Calculate value $b_{i}$ and $e_{i}$

2. Calculate the range based on the level of interest of the graduate $\left(b_{i}\right)$ dan user satisfaction $\left(e_{i}\right)$

3. Calculate the value of the attitude $A_{o}$

\section{RESULT AND DISCUSSION}

The following are the results of the descriptive analysis in the tracer study that we conducted in 2019 , shown in Figure 2.

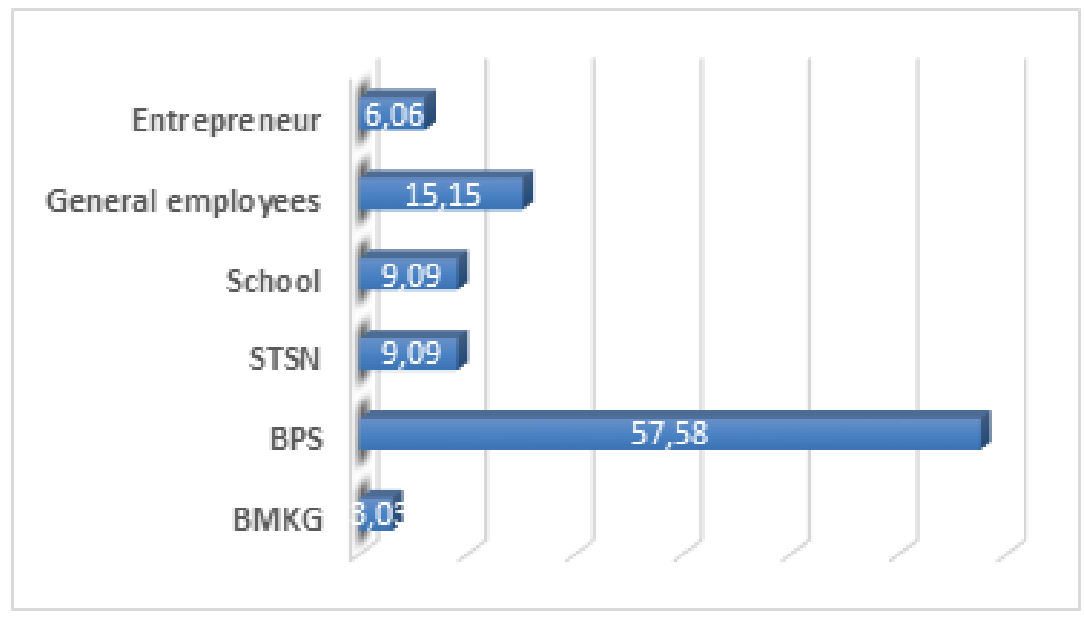

Figure 2. The Work of The Graduates

Figure 2 explains that statistics graduates who are the most respondent in the 2019 tracer study are graduates who have worked in BPS agencies (57.58\%), private employees (15.15\%), and the rest in other fields with a percentage below $10 \%$. It can be concluded that $100 \%$ of graduates who at that time have worked and they continue their education to S1 Statistics with the hope of increasing competence in the field of Statistics.

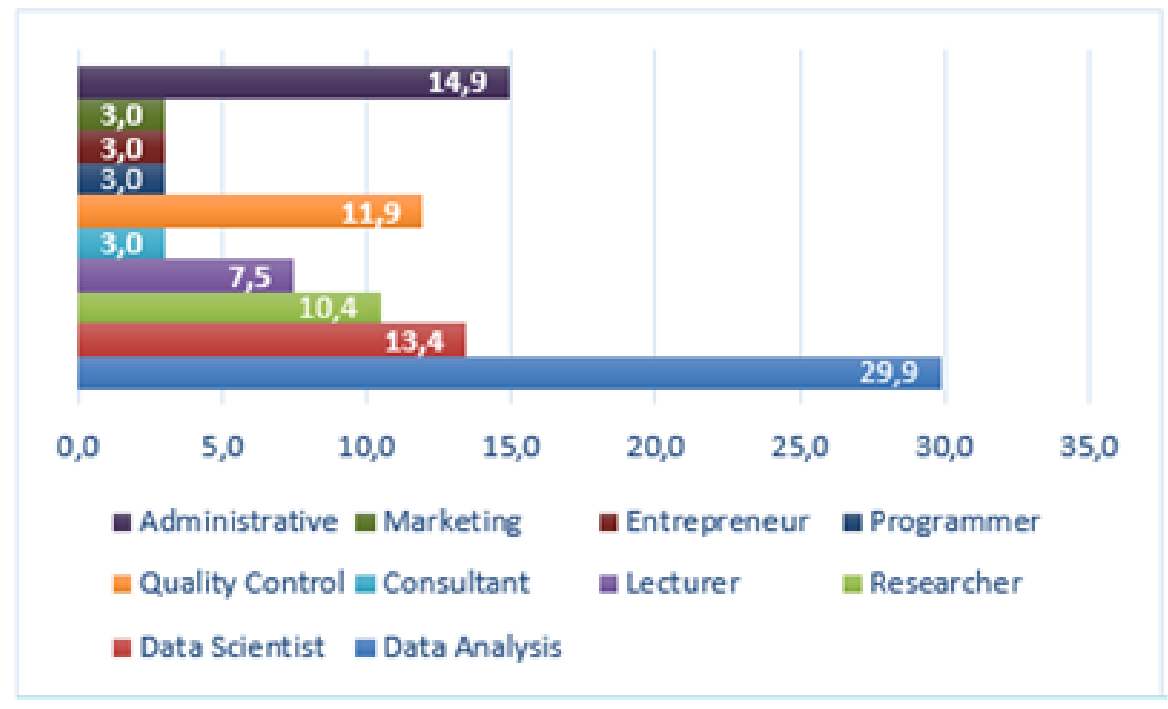

Figure 3. User Expectations of Graduates in Employment 
Figure 3 explains that according to users, 3 top rankings become their hopes for graduates, namely experts in the fields of data analysis (29.9\%), administrative (14.9\%), and data scientist (13.4\%). Administrative is ranked second because statistician users, must be able to implement the results of the analysis they do in research into reports (papers/journals). Furthermore, the validity test was carried out on the tracer study data with the following results:

Table 4. Multicollinearity Test of Linear Regression Model

\begin{tabular}{cccccc}
\hline \multirow{2}{*}{ Attribute } & $\begin{array}{c}\text { Total Score } \\
\text { Pearson Correlation }\end{array}$ & Sig. (2-tailed) & Item & $\begin{array}{c}\text { Total Score } \\
\text { Pearson Correlation }\end{array}$ & Sig. (2-tailed) \\
\hline 1 & 0.481 & 0.005 & 16 & 0.523 & 0.002 \\
2 & 0.509 & 0.003 & 17 & 0.517 & 0.002 \\
3 & 0.796 & 0.000 & 18 & 0.704 & 0.000 \\
4 & 0.361 & 0.039 & 19 & 0.658 & 0.000 \\
5 & 0.480 & 0.005 & 20 & 0.401 & 0.021 \\
6 & 0.517 & 0.002 & 21 & 0.505 & 0.003 \\
7 & 0.705 & 0.000 & 22 & 0.555 & 0.001 \\
8 & 0.736 & 0.000 & 23 & 0.636 & 0.000 \\
9 & 0.584 & 0.000 & 24 & 0.636 & 0.000 \\
10 & 0.524 & 0.002 & 25 & 0.587 & 0.000 \\
11 & 0.499 & 0.003 & 26 & 0.419 & 0.015 \\
12 & 0.649 & 0.000 & 27 & 0.637 & 0.000 \\
13 & 0.450 & 0.009 & 28 & 0.687 & 0.000 \\
14 & 0.512 & 0.002 & 29 & 0.580 & 0.000 \\
15 & 0.573 & 0.001 & 30 & 0.529 & 0.002 \\
\hline
\end{tabular}

Based on the Table 4, the Pearson Correlation value or count on the attribute 1 to $15>r_{(33-2)}=0.344$ or P-Value $<0.05$ it can be concluded that all of these items are valid. In addition, the value of Cronbach's Alpha score is $0.718>0.6$. So all items 1 to 15 are reliable. Furthermore, the 15 attributes are calculated for the Gap value and the level of conformity and the results are in Table 5 .

Table 5. Gap and Suitability Level

\begin{tabular}{ccccc}
\hline Attribute & Importance & Performance & Gap & Level of conformity \\
\hline 1 & 3.27 & 3.12 & -0.15 & 95.41 \\
2 & 3.15 & 3.06 & -0.09 & 97.14 \\
3 & 3.36 & 3.18 & -0.18 & 94.64 \\
4 & 3.33 & 3.18 & -0.15 & 95.50 \\
5 & 3.21 & 3.00 & -0.21 & 93.46 \\
6 & 3.30 & 3.00 & -0.30 & 90.91 \\
7 & 3.36 & 3.15 & -0.21 & 93.75 \\
8 & 3.39 & 3.36 & -0.03 & 99.12 \\
9 & 3.39 & 3.18 & -0.21 & 93.81 \\
10 & 3.30 & 3.00 & -0.30 & 90.91 \\
11 & 3.64 & 3.48 & -0.15 & 95.60 \\
12 & 3.52 & 3.12 & -0.39 & 88.64 \\
13 & 3.39 & 2.94 & -0.45 & 86.73 \\
14 & 3.48 & 3.03 & -0.45 & 87.07 \\
15 & 3.42 & 3.09 & -0.33 & 90.35 \\
Average & 3.37 & 3.13 & -0.24 & 92.87 \\
\hline
\end{tabular}

Based on the Table 5, the Gap value for 15 indicators is negative, so these 15 indicators have not been able to meet user expectations of graduates. The highest Gap value is -0.45 which is located on indicators 13 and 14 , namely the ability of graduates 
to have new ideas and present (ideas, results, or reports) so that the 2 indicators are included in the top priority to be improved by graduates to meet user expectations. Meanwhile, based on the level of conformity on the 15 indicators studied, the overall category is very good $92.87 \%$.

Paired test analysis and Importance-Performance Analysis, with the following hypotheses:

$H_{0}$ : There is no difference between importance and performance

$H_{1}$ : There is a difference between importance and performance

Table 6. Test Samples in Pairs

\begin{tabular}{cccc}
\hline Variable & $\mathrm{t}$ & $\mathrm{df}$ & Sig. (2-tailed) \\
\hline Importance Performance & 7.380 & 14 & 0.00 \\
\hline
\end{tabular}

Based on the Table 6, the value of P-value $=0.00<\alpha=0.05$, then Reject H0 there is a difference between importance and performance or it can be concluded that there is a difference between user satisfaction and the importance of graduate ability.

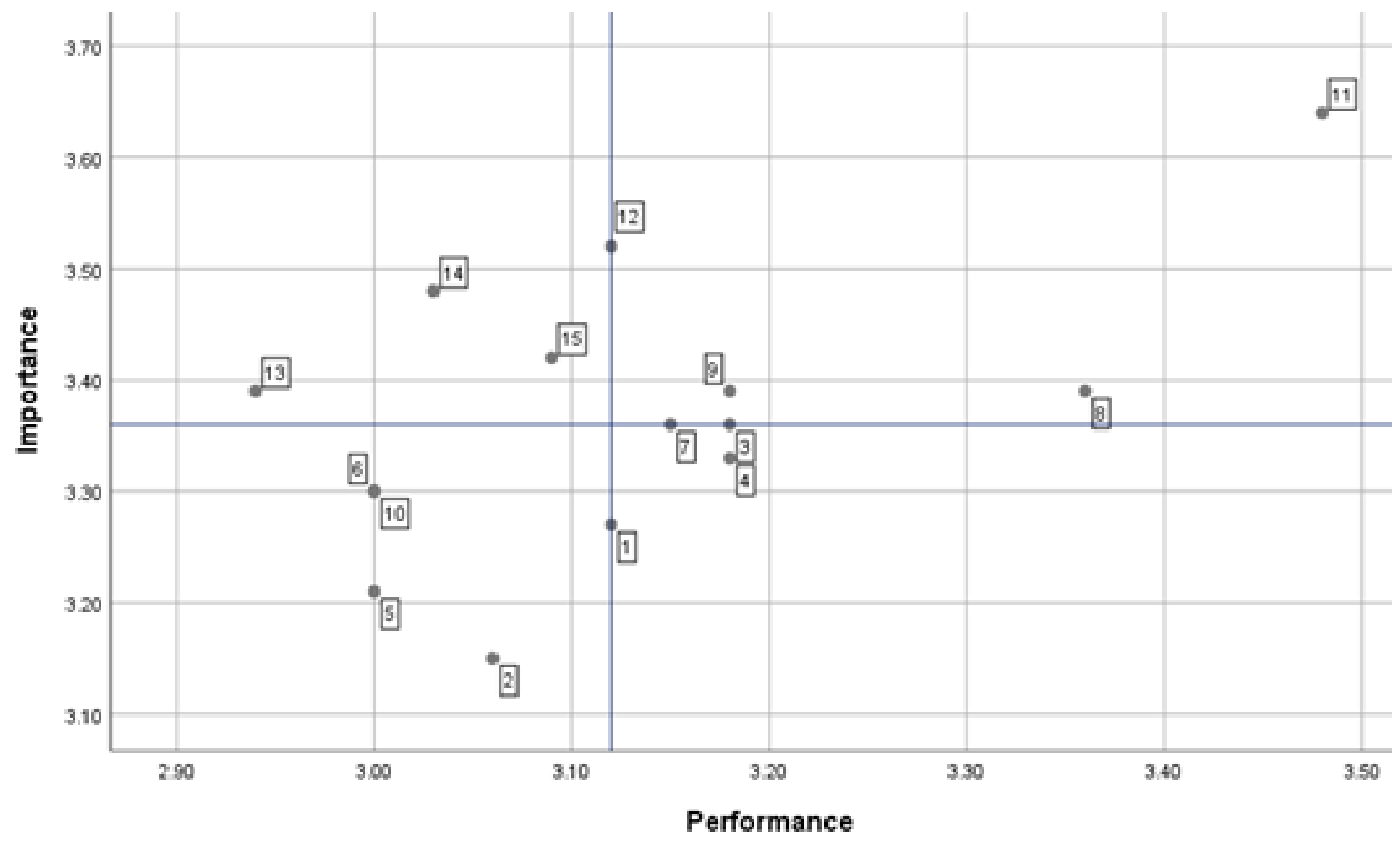

Figure 4. Importance-Performance Analysis Results

Based on Figure 4, there are several indicators found on the average line so that the authors categorize these indicators based on their closeness to other indicators, we can conclude as follows: Quadrant I : the ability of graduates in quadrant I am the main priority that graduates need to improve according to user expectations, namely indicators 12,13,14, and 15 (Problem-solving skills, generate ideas, present the results of ideas, and write reports.

Quadrant II : users want graduates to maintain their abilities on indicators 7, 8, 9, and 11 (coordinate activities, manage time efficiently, work productively with others, and use a computer or the internet).

Quadrant III : users prioritize the ability of graduates a little in indicators 1, 2, 5, 6, and 10 (mastery of fields of science taken at UT, knowledge of other fields of science, negotiate effectively, perform well under pressure, and empower others).

Quadrant IV : indicators included in this quadrant are 3 and 4 (analytical thinking, and the ability to acquire new knowledge quickly). 
After analyzing the Gap and Importance-Performance. Researchers calculate user satisfaction with graduate performance based on CSI with the following results:

Table 7. Customer Satisfaction Index (CSI)

\begin{tabular}{cccccccc}
\hline Importance & MIS & WF & WS & Performance & MSS & WT & CSI \\
\hline h1 & 3.27 & 0.06 & 0.20 & $\mathrm{k} 1$ & 3.12 & 3.13 & 78.25 \\
h2 & 3.15 & 0.06 & 0.19 & $\mathrm{k} 2$ & 3.06 & & \\
h3 & 3.36 & 0.07 & 0.21 & $\mathrm{k} 3$ & 3.18 & & \\
h4 & 3.33 & 0.07 & 0.21 & $\mathrm{k} 4$ & 3.18 & & \\
h5 & 3.21 & 0.06 & 0.19 & $\mathrm{k} 5$ & 3.00 & \\
h6 & 3.30 & 0.07 & 0.20 & $\mathrm{k} 6$ & 3.00 & \\
h7 & 3.36 & 0.07 & 0.21 & $\mathrm{k} 7$ & 3.15 & \\
h8 & 3.39 & 0.07 & 0.23 & $\mathrm{k} 8$ & 3.36 & \\
h9 & 3.39 & 0.07 & 0.21 & $\mathrm{k} 9$ & 3.18 & & \\
h10 & 3.30 & 0.07 & 0.20 & $\mathrm{k} 10$ & 3.00 & & \\
h11 & 3.64 & 0.07 & 0.25 & $\mathrm{k} 11$ & 3.48 & \\
h12 & 3.52 & 0.07 & 0.22 & $\mathrm{k} 12$ & 3.12 & & \\
h13 & 3.39 & 0.07 & 0.20 & $\mathrm{k} 13$ & 2.94 & & \\
h14 & 3.48 & 0.07 & 0.21 & $\mathrm{k} 14$ & 3.03 & & \\
h15 & 3.42 & 0.07 & 0.21 & $\mathrm{k} 15$ & 3.09 & & \\
Amount & 50.55 & & & & &
\end{tabular}

Based on the Table 7, the CSI value is $78.25 \%$, it can be concluded that user satisfaction with the interests of the ability of graduates is good even though based on the Gap value of 15 the indicators have not met user expectations, but overall user satisfaction with graduates is good.

Table 8. Fishbein Results

\begin{tabular}{cccc}
\hline bi & ei & bi * ei & Ao \\
\hline 3.27 & 3.12 & 10.21 & 158.20 \\
3.15 & 3.06 & 9.65 & \\
3.36 & 3.18 & 10.70 & \\
3.33 & 3.18 & 10.61 & \\
3.21 & 3.00 & 9.64 & \\
3.30 & 3.00 & 9.91 & \\
3.36 & 3.15 & 10.60 & \\
3.39 & 3.36 & 11.42 & \\
3.39 & 3.18 & 10.80 & \\
3.30 & 3.00 & 9.91 & \\
3.64 & 3.48 & 12.67 & \\
3.52 & 3.12 & 10.97 & \\
3.39 & 2.94 & 9.98 & \\
3.48 & 3.03 & 10.56 & \\
3.42 & 3.09 & 10.58 & \\
\hline
\end{tabular}

Based on Table 8, an Ao value of 158.20 is obtained. Based on the criteria for user attitudes towards graduates, the user's attitude towards graduates of the Statistics study program is positive.

\section{E. CONCLUSION AND SUGGESTION}

The Gap value on 15 indicators is negative, so the 15 indicators have not been able to meet the user's expectations of graduates. Improvement in the quality of graduate performance starts at the biggest to the smallest negative gap. The biggest gap value is -0.45 
which is located on indicators 13 and 14, namely The ability to generate ideas and present the results of ideas, so these 2 indicators are the top priority that must be improved by graduates to meet user expectations. Based on the Importance-Performance Analysis, the ability of graduates is the main priority so that it needs to be improved, namely those based on quadrant I such as problemsolving skills, generate ideas, present the results of ideas, and write reports. The level of conformity between user satisfaction and the importance of the ability of graduates on the 15 attributes studied as a whole is in the very good category $92.87 \%$. CSI value is $78.25 \%$, which means that overall user satisfaction with graduates is good. The results of the multi-attribute Fishbein model obtained an Ao value of 158.20. Based on these results, user perceptions of graduates produce positive attitudes.

\section{ACKNOWLEDGEMENT}

The author would like to thank The Universitas Terbuka and the lecturers for their assistance so that this research can run well.

\section{REFERENCES}

Abrami, P. C., Bernard, R. M., Bures, E. M., Borokhovski, E., and Tamim, R. M. (2011). Interaction in Distance Education and Online Learning: Using Evidence and Theory to Improve Practice. Journal of Computing in Higher Education, 23(2-3):82-103.

Arabia, S. (2021). The Satisfaction Level of Undergraduate Science Students Towards Using E-Learning and Virtual Classes in Exceptional Condition Covid-19 Crisis. (January):52-65.

Feng, M., Mangan, J., Wong, C., Xu, M., and Lalwani, C. (2014). Investigating The Different Approaches to ImportancePerformance Analysis. Service Industries Journal, 34(12):1021-1041.

Fidalgo, P., Thormann, J., Kulyk, O., and Lencastre, J. A. (2020). Students' Perceptions on Distance Education: A Multinational Study. International Journal of Educational Technology in Higher Education, 17(1).

Jasuli (2018). Analysis of Student Attitudes Towards E-Learning Using Fishbein Multiattribute Approach. IOP Conference Series: Materials Science and Engineering, 296(1).

Kumari, P. (2020). Comparing Customer Attitude Towards Amazon and Flipkart in Patna. International Research Journal on Advanced Science Hub, 2(Special Issue ICSTM 12S):4-8.

Kumi-Yeboah, A., Kim, Y., Sallar, A. M., and Kiramba, L. K. (2020). Exploring The Use of Digital Technologies From The Perspective of Diverse Learners in online Learning Environments. Online Learning Journal, 24(4):42-63.

Lassoued, Z., Alhendawi, M., and Bashitialshaaer, R. (2020). Education Sciences An Exploratory Study of The Obstacles for Achieving Quality in Distance Learning During The. Education Sciences, 10:1-13.

Lubis, S. N., Fauzia, L., and Utami, D. (2020). CSI (Customer Satisfaction Index) and IPA (Importance Performance Analysis) of Mandheling Coffee in Medan. IOP Conference Series: Earth and Environmental Science, 454(1).

Picciano, A. G. (2017). Theories and Frameworks For Online Education: Seeking An Integrated Model. Online Learning Journal, 21(3):166-190.

Renny, Chandra, R., Ruhama, S., and Sarjono, M. W. (2013). Exploring Tracer Study Service in Career Center Web Site of Indonesia Higher Education. 11(3):36-39.

Silva, F. and Fernandes, P. (2010). Using Importance-Performance Analysis in Evaluating Institutions of Higher Education: A Case Study. ICEMT 2010 - 2010 International Conference on Education and Management Technology, Proceedings, (January 2014):121-123.

Taber, K. S. (2018). The Use of Cronbach's Alpha When Developing and Reporting Research Instruments in Science Education. Research in Science Education, 48(6):1273-1296.

Vieira, E., Ferreira, J. J., and São João, R. (2019). Creation of Value for Business From The Importance-Performance Analysis: The Case of Health Clubs. Measuring Business Excellence, 23(2):199-215. 
Wade, D. J. and Eagles, P. F. (2003). The Use of Importance-Performance Analysis and Market Segmentation for Tourism Management in Parks and Protected Areas: An Application to Tanzania's National Parks. Journal of Ecotourism, 2(3):196-212.

Widayanti, S., Amir, I. T., Indah, P. N., and Septya, F. (2020). Consumer Preference of Packaged Rice and Bulk Rice in Surabaya. HOLISTICA Journal of Business and Public Administration, 11(1):155-169.

Yanova, N. (2015). Assessment of Satisfaction with The Quality of Education: Customer Satisfaction Index. Procedia - Social and Behavioral Sciences, 182:566-573. 